\title{
Impact of different temperature profiles on simultaneous yeast and bacteria fermentation
}

\author{
Raffaele Guzzon * (1D, Tomas Roman and Roberto Larcher
}

\begin{abstract}
Purpose: The role of fermentation temperature was studied for its impact on the evolution of malolactic fermentation performed by simultaneous inoculum of yeast and bacteria in grape must. Results were discussed considering the different fermentative kinetics and the composition of obtained wines.

Methods: Two strains of bacteria belonging to the O. oeni and L. plantarum species were inoculated $24 \mathrm{~h}$ after the beginning of the alcoholic fermentation in 2 grape musts having different acidic and sugar profiles. Fermentations were conducted at 3 different temperature profiles $\left(16 / 22{ }^{\circ} \mathrm{C}\right.$ in 3 days, $18 / 24{ }^{\circ} \mathrm{C}$ in 3 days, $22 / 32{ }^{\circ} \mathrm{C}$ in 5 days). Evolution of microbiota was followed by flow cytometry and plate count. Chemical analysis of grape musts and wines were performed by instrumental approaches (FT-IR, enzymatic quantification of malic acid, GC-MS).

Results: L. plantarum resulted more efficient in malic acid consumption in the entire set of tests. These results are unexpected because, generally, Lactobacillus has been reported to be more sensitive to an oenological environment than $O$. oeni. In our experiments, $O$. oeni resulted inhibited by the highest fermentation temperature profile, causing incomplete malic acid degradation. Similarly, S. cerevisiae showed a higher sensitivity to environmental limiting factors in respect to what is generally known. Differences in the chemical composition of wines were observed in relation to the bacteria strain and the temperature profile. However, the statistical treatment of data identified temperature as the main variable able to influence the features of wines.

Conclusions: Simultaneous inoculum of yeast and bacteria in grape must is an alternative approach in the management of malolactic fermentation which showed some interesting features. However, it is necessary to consider that the dynamics of the microbial population are different to that observed in traditional winemaking and the environmental variables act against the microorganisms in a peculiar, and in certain cases unexpected, way.
\end{abstract}

Keywords: Malolactic fermentation, Simultaneous inoculum, Oenococcus oeni, Lactobacillus plantarum, Temperature, Wine

\section{Introduction}

Malolactic fermentation (MLF) is a key step in winemaking which allows the achievement of numerous objectives relevant to wine quality (Liu 2002). In the first instance, MLF leads to the degradation of malic acid, through an intracellular reaction of decarboxylation,

\footnotetext{
* Correspondence: raffaele.guzzon@fmach.it

Centro di Trasferimento Tecnologico, Fondazione Edmund Mach, Via Mach 1 38010 San Michele all'Adige, Trento, Italy
}

mediated by a specific enzyme. This process is necessary for lactic bacteria (belonging to the genera Oenococcus sp., Pediococcus sp., and Lactobacillus sp.) to obtain energy in wine, a harsh environment having generally lack of sugars (Battermann and Radler 1991; Wang et al. 2016). The substitution of L-malic acid with L-lactic acid gives a more pleasant palate to wine, reducing its harshness. However, the degradation of L-malic acid is not the only effect of lactic bacteria activity in wine (Liu 2002). These microorganisms are able to metabolize

(c) The Author(s). 2020 Open Access This article is licensed under a Creative Commons Attribution 4.0 International License, which permits use, sharing, adaptation, distribution and reproduction in any medium or format, as long as you give appropriate credit to the original author(s) and the source, provide a link to the Creative Commons licence, and indicate if changes were made. The images or other third party material in this article are included in the article's Creative Commons licence, unless indicated otherwise in a credit line to the material. If material is not included in the article's Creative Commons licence and your intended use is not permitted by statutory regulation or exceeds the permitted use, you will need to obtain permission directly from the copyright holder. To view a copy of this licence, visit http://creativecommons.org/licenses/by/4.0/. 
numerous components from which derive molecules having an organoleptic impact. Diacetyl and subsequently acetoin and butanediol are obtained from the catabolism of citric acid. There is a redox equilibrium between these molecules which gives aroma notes described as "lactic" or "buttery," usually characterizing the bouquet of wines in which MLF occurred (Nielsen and Richelieu 1999, Lasik-Kurdyś et al. 2018). Other relevant classes of compounds influenced by the occurrence of lactic bacteria in wine are the higher alcohols, the glycerol, and the acetic acid due to the metabolism of sugars (Herrero et al. 1999a, 1999b). Lactic acid bacteria are also able to promote, on the one hand, the release of bound varietal aromas through their $\beta$-glucosidase and $\beta$-lyasis (Smit et al. 2005, Michlmayr and Kneifel 2014) and on the other, modification of the ester profile of wines due to the esterasic activity (Matthews et al. 2004). From the microbiological point of view, the occurrence of MLF stabilizes the wine due to the elimination of carbon sources, organic acids, and sugars, not fully consumed by yeast during the AF. This effect is beneficial to prevent wine spoilage due to "wild" lactic bacteria or yeast, especially belonging to the Brettanomyces sp. genera (Bartowsky 2009).

In view of the interest for a reliable evolution of MLF in terms of the rate of fermentation and the quality of obtained wines, in past years a few researchers have turned their attention toward the factors that are able to regulate bacterial activity in wine and to improve the strategies to facilitate the evolution of this important biologic process (Betteridge et al. 2015; Sumby et al. 2014, 2019). Wine is a harsh environment for bacteria due to the simultaneous occurrence of some limiting factors. Among these, the most known are the acidity, the presence of ethanol and sulfur dioxide, and the lack of nutritional factors such as sugars or nitrogen compounds. More recently, researchers have focused the role of phenolic molecules (tannins coming from grapes or wooden barrels) and of compounds originated from yeasts, such as fatty acids which counteract the development and the activity of lactic acid bacteria in wine (Guerzoni et al. 1995; Guzzon et al. 2009, 2013). In addition to these variables, some technological choices, made by winemakers, could promote or interfere with the evolution of MLF. Subtractive practices, such as the clarification of wine, are detrimental to bacteria because they eliminate nutrients and reduce the microbial load derived from grapes (Liu 2002). A great role is also played by the yeast strain that performs alcoholic fermentation. This must be carefully chosen by considering its compatibility with the bacteria that will be used for MLF (Costello et al. 2008). Other technological variables influencing the evolution of MLF are the methods and the duration of the pomace maceration in grape must, the racking of wine, the oxygen availability during MLF, the presence of yeast lees during wine aging, the addition of specific nutrients for bacteria at the end of $\mathrm{AF}$, or the use of chemical compounds with toxic action toward bacteria, such as lysozyme or chitosan (Azzolini et al. 2010, Elmac et al. 2014). For each of these, the limits beyond which bacterial activity can be compromised are now known. However, the incidence of these limiting factors against lactic acid bacteria is frequently regulated by agri-environmental variables, the protocol of winemaking or the technical and organizational limitations that characterize each winery. Therefore, the possibility of modulating these variables to improve the fitness of lactic bacteria during MLF is limited.

There are two other winemaking parameters that can strongly regulate bacterial activity, which are less constrained by the limits described above: the fermentation temperature and the timing of inoculation of the lactic bacteria in wine (Guerzoni et al. 1995, Garbay et al. 1995, Herrero et al. 1999a, 1999b, Guzzon et al. 2013). With regard to the fermentation temperature, its impact on alcoholic and malolactic fermentation kinetics and on the qualitative outcomes is known. Temperature fluctuations in the range that is usual in wineries, from 15 to $32{ }^{\circ} \mathrm{C}$, can affect the fermentation rate, the extraction mechanisms from grape skins, the production of secondary metabolites with a significant organoleptic impact, and the preservation of varietal aromas liberated from grapes during fermentation (Herrero et al. 1999a, 1999b, Bordiga et al. 2016, Setford et al. 2018, Schwinn et al. 2019). The use of "cold" in cellars is a very ancient practice, traditionally obtained by building underground wineries, modulating the dimensions and materials of the vats destined for the oenological fermentations, refreshing them by cold water or, in extreme cases, by ice to lower wine temperature. In the case of MLF, the low temperatures that characterize the cellars in the months following the harvest are a critical parameter because it is proven that bacterial activity significantly slows down below $18{ }^{\circ} \mathrm{C}$, and stops at $10{ }^{\circ} \mathrm{C}$ (Liu 2002; Guzzon et al. 2009). Moreover, the low temperatures favor the settling of bacteria and the precipitation of insoluble tartrate salts that limit the mass exchange rate between wine and bacteria. On the contrary, excessive temperatures could increase the sensitivity of bacteria to ethanol, altering cell membrane permeability.

The timing of bacteria inoculation is the second topic in the management of MLF. About 10 years ago, it was believed that bacteria had to be added to the wine at the end of AF, when sugars are exhausted, to avoid risks of alteration (Lonvaud-Funel 1999). However, a new generation of starter strains has been specifically selected for their absence of alterative activities and good compatibility with yeast, thus making it possible to anticipate the 
timing of inoculation of lactic bacteria at the early stages of alcoholic fermentation (Jussier et al. 2006, Taniasuri et al. 2006, Guzzon et al. 2013). The solution's advantages are numerous (Alexandre et al. 2004). The stress of the bacteria's adaptation to wine conditions is reduced because microorganisms develop in an environment that still contains low quantities of ethanol and sulfur dioxide. In addition, the early inoculation of lactic bacteria allows for obtaining sensorial profiles different from those wine characteristics that result from a successive inoculum of yeasts and bacteria. This innovative approach to MLF is nowadays very popular among winemakers; however, it requires a re-evaluation of the effect of wine-limiting factors against bacteria in this new scenario.

This work studies the impact of different temperature profiles, simulating what is commonly done in wineries in the early stage of winemaking, on the dynamics of alcoholic and malolactic fermentation and on the aromatic profile of obtained wines. Two different yeast-bacteria pairs were considered, exploring the behavior of obligatory hetero- and facultative hetero-fermentative strains belonging to the $O$. oeni and L. plantarum species. The experiments were carried out simulating the temperature profiles usually observed during winemaking: a sudden increase in the first days of fermentation, often close to $30{ }^{\circ} \mathrm{C}$ and subsequently, a constant temperature depending on the characteristics of the cellar and of the wine vessels. The combination of the two variables explored ensures a significant contribution to knowledge on the management of this winemaking process' crucial step.

\section{Materials and methods}

\section{Microorganisms and materials involved in experimental} winemaking

Winemaking experiments were carried out on two grape musts ( $c v$. Chardonnay) obtained at the winery of the Edmund Mach Foundation (I). The main chemical parameters of grape musts are the following. Grape must 1 (G1): sugars $202 \mathrm{~g} / \mathrm{L}, \mathrm{pH}$ 3.12, L-malic acid $3.55 \mathrm{~g} / \mathrm{L}$, readily assimilable nitrogen $180 \mathrm{mg} / \mathrm{L}$. Grape must 2 (G2): sugars $234 \mathrm{~g} / \mathrm{L}, \mathrm{pH} 3.48$, L-malic acid 2.87, readily assimilable nitrogen $115 \mathrm{mg} / \mathrm{L}$. Yeast Lalvin ICV D47 (Lallemad Inc., CA) was employed to start AF, while Oenococcus oeni A4 (Lallemad Inc.) and Lactobacillus plantarum $\mathrm{K} 45 \mathrm{H}$ (Lallemad Inc.) were employed to drive MLF. Fermaid E (Lallemad Inc.) was used as a nitrogen supplement during $\mathrm{AF}(0.2 \mathrm{~g} / \mathrm{L}$ at the beginning of $\mathrm{AF}$ and $0.2 \mathrm{~g} / \mathrm{L}$ after $1 / 3$ of $\mathrm{AF}$ ).

\section{Experimental winemaking}

Winemaking from each grape must (G1 and G2) was performed by utilizing yeast and bacteria in simultaneous fermentations. Both experiments were carried out in $1 \mathrm{~L}$ glass bottles $(n=2)$, we applied 3 different temperature profiles. In the first test (T1), the grape must temperature was initially set to $16{ }^{\circ} \mathrm{C}$ and subsequently increased up to $22^{\circ} \mathrm{C}$ within a period of 3 days. After that, the temperature remained constant for the entire duration of the fermentation process. The second temperature protocol (T2) showed a similar dynamic to the $\mathrm{T} 1$, but started from $18{ }^{\circ} \mathrm{C}$ and reached $24{ }^{\circ} \mathrm{C}$. The third protocol (T3) has an initial temperature of $20{ }^{\circ} \mathrm{C}$ and a maximum temperature of $32{ }^{\circ} \mathrm{C}$, which was reached in 5 days. In $\mathrm{T} 1$ and $\mathrm{T} 2$, the temperature was augmented by $2{ }^{\circ} \mathrm{C}$ every $24 \mathrm{~h}$; in $\mathrm{T} 3$, the temperature was increased by $3{ }^{\circ} \mathrm{C}$ every day. Yeast was inoculated into grape must at a concentration of $0.3 \mathrm{~g} / \mathrm{L}$. In the case of bacteria, we employed an inoculum of $0.01 \mathrm{~g} / \mathrm{L}$ of freeze-dried culture for the $O$. oeni strain and $0.1 \mathrm{~g} / \mathrm{L}$ for the L. plantarum strain. The ratio of inoculum of the two LAB strains is related to the different behavior in wine, as will be discussed in the "Discussion" section of this work. Selected microbial cultures were rehydrated according to the OIV standard (OIV 2019) and lactic bacteria were added to the fermenting grape must $24 \mathrm{~h}$ after the beginning of AF. AF fermentation was followed by the daily measuring of weight loss due to $\mathrm{CO}_{2}$ production; L-malic acid was measured by enzymatic assay as reported in the next paragraph. At the end of fermentations, the vessels that contained wines were saturated by $\mathrm{N}_{2}$, cold stored $\left(5{ }^{\circ} \mathrm{C}\right)$ for 7 days, and racked to eliminate the excess of yeast lees. The wines were submitted to chemical investigations after 1 month of aging at $10{ }^{\circ} \mathrm{C}$.

\section{Microbiological analysis}

All analyses were performed in the Edmund Mach Foundation laboratory of microbiology that operates according to the (ISO/IEC 17011 2017). The count of viable and dead yeast cells was performed by flow cytometry (FCM) (Guzzon and Larcher 2015). One milliliter of sample containing approximately $10^{5}$ cells, obtained by an appropriate dilution in a PBS buffer, was filtered through a $30 \mu \mathrm{m}$ filter (CellTrics ${ }^{\circledR}$, Partec-Sysmex GHB, D) and incubated for $10 \mathrm{~min}$ at $20^{\circ} \mathrm{C}$ in the presence of $10 \mu \mathrm{L}$ of a $5 \mathrm{mg} / \mathrm{mL}$ fluorescein diacetate solution (Partec-Sysmex). After incubation, samples were mixed and added to $10 \mu \mathrm{L} 2 \mathrm{mg} / \mathrm{mL}$ of propidium iodide solution (Partec-Sysmex). The double-stained samples were homogenized (30" by a Vortex apparatus, IKA, S) and submitted to FCM analysis within $10 \mathrm{~min}$. FCM analysis was performed by a CUBE 8 Cytometer (Partec-Sysmex), equipped with a solid blue laser emitting at $488 \mathrm{~nm}$. We considered the following signals by means of four bandpass filters: a forward-angle light scatter (FSC) combined, a side-angle light scatter (SSC), and 2 fluorescence signals, the first by a $530 \mathrm{~nm}$ band-pass filter to 
collect green fluorescence (FL1 channel), and the second by a $630 \mathrm{~nm}$ long-pass filter to collect red fluorescence (FL2 channel). FCM analyses were performed using logarithmic gains and specific detector settings, adjusted on a sample of unstained Saccharomyces cerevisiae ATTC 9763 to eliminate the background and the auto fluorescence of cells. Data were analyzed using the FCS Express 4 software (De Novo Software Inc., CA). Yeast cell population was identified and gated in the dot plot FSC/SSC; a live and dead cell differentiation was performed in the dot plot FL1/FL2, adjusted by the appropriate compensation between the two signals considering the subpopulation of yeast gated in the dot plot FSC/SSC. Lactic bacteria quantification was performed by plate count (OIV 2019) using MRS agar (Oxoid, UK) supplemented by $20 \% \mathrm{v} / \mathrm{v}$ of apple juice and $1 \% \mathrm{v} / \mathrm{v}$ of a $0.1 \%$ cicloeximide solution (Oxoid). After sample spreading, Petri plates were incubated at $25{ }^{\circ} \mathrm{C}$ for 10 days under anaerobic conditions using an Anaerogen Kit (Oxoid).

\section{Chemical analysis}

Chemical parameters of the grape must (sugars, $\mathrm{pH}$, Lmalic acid, and readily assimilable nitrogen) and wines (ethanol, $\mathrm{pH}$, sugars, total acidity, acetic acid) were monitored using FT-IR (FOSS, DK). L-malic acid quantification was carried out by an enzymatic detector Miura 200 (Biogamma, I). The volatile profiles of obtained wines were determined after preparation of the samples using solid phase extraction (SPE, ENV+ cartridge), as proposed by Boido et al. (2003). Volatile compound analysis was performed with GC-MS/MS using a Varian 450 (Agilent Technologies) chromatograph coupled to a Varian 300 TQMS tandem mass spectrometer (Agilent Technologies). The sample extract was injected $(1 \mu \mathrm{L})$ in splitless mode. The injector temperature was $250{ }^{\circ} \mathrm{C}$. Chromatographic separation was performed using a VFWAXms $(30 \mathrm{~m} \times 0.25 \mathrm{~mm}$ ID $\times 0.25 \mu \mathrm{m}$ film thickness, Agilent Technologies) capillary column with the following oven temperature program: $40{ }^{\circ} \mathrm{C}$ for $5 \mathrm{~min}$, raised to 150 ${ }^{\circ} \mathrm{C}$ at $5{ }^{\circ} \mathrm{C}$ min- -1 , finally raised to $240{ }^{\circ} \mathrm{C}$ at $10{ }^{\circ} \mathrm{C}$ min- 1 and held for $10 \mathrm{~min}$. The mass spectrometer was equipped with an electron impact ionization source (EI) $(70 \mathrm{eV}, 50$ $\mu \mathrm{A})$ and acquisition was performed in multiple reaction monitoring (MRM) mode. The transitions and collision energies were those reported by Vrhovsek et al. (2004).

\section{Statistical analysis}

Results of physico/chemical and microbiological observations were expressed as mean $\pm \mathrm{SD}$ of the 3 or 6 replicates, as detailed in the following chapter. Statistical analysis of the data was carried out using the Statistica 7.1 software (StatSoft, Tulsa, OK). The variance among cases (LAB strains) or variables (temperature profiles) in the determining of chemical parameters of wines was studied by two-way ANOVA test, $p=0.05$. Principal component analysis (PCA) was performed to grouping the wines on the basis of the entire volatile profile.

\section{Results \\ Effect of different temperature profiles on oenological fermentations}

Figure $1 \mathrm{a}, \mathrm{b}$, and c shows the weight loss curves related to the glucose + fructose consumption and the L-malic acid degradation observed in the winemaking tests performed using the two bacterial strains, in function of the different fermentation temperature profiles. G1 was obtained from early harvested grapes, simulating what is commonly done in the production of sparkling wines. The increase in temperature of the 3 experiments (T1, T2, and T3) stimulates the sugar consumption rate. Indeed, the differences observed between the evolution of AF performed in G1 with the two strains of bacteria ( $\mathrm{K} 45 \mathrm{H}$ and $\mathrm{A} 4)$ were not significant from a statistical point of view; therefore, data are expressed as the mean of the entire set of experiments performed at the same temperature. In $\mathrm{T} 1, \mathrm{AF}$ required 14 days while in $\mathrm{T} 2$ and T3, the degradation of sugars stopped after 11 and 9 days, respectively. The initial temperature of grape must influenced the duration of lag-phase (Fig. 1) and the $V_{\max }$ of the 3 experimental trials. These are $(n=6)$ : in $\mathrm{T} 1,2.7 \pm 0.3 \mathrm{~g} \mathrm{CO}_{2} \mathrm{~L}^{-1}$ day $^{-1}$, in $\mathrm{T} 2,4.0 \pm 0.3 \mathrm{~g} \mathrm{CO}_{2}$ $\mathrm{L}^{-1}$ day $^{-1}$, and in T3, $4.5 \pm 0.4 \mathrm{~g} \mathrm{CO}_{2} \mathrm{~L}^{-1}$ day $^{-1}$. In G1, the Lactobacillus strain demonstrated the best MLF performance at all the temperature profiles adopted (Fig. 1, $n=3$ ). Independently, of the grape must's initial temperature, $L$. plantarum $\mathrm{K} 45 \mathrm{H}$ showed 2 days of lagphase to start L-malic acid consumption and MLF was accomplished in 13 days (T1 and T3) or 7 days (test $\mathrm{T} 2$ ). $O$. oeni A4 showed the same lag phase (2 days), but the degradation rate of L-malic acid was slower, accomplishing MLF in 18 days in the case of T1, 13 days in the T2 test, and it resulted unable to completely degrade Lmalic acid at the highest temperature profile (T3).

G2 was derived from grapes harvested at plain ripeness, characterized by a lower acid content and higher sugar concentration with respect to G1. According to the previous tests, the presence of lactic bacteria did not interfere with $\mathrm{AF}$, which trend is related to the increase of temperature (Fig. 2 a, b, and c). In G2T1 and G2T2, alcoholic fermentation required 16 and 12 days respectively, while in G2T3 the degradation of sugars stopped after 10 days. The delay with respect to G1 experiments on the conclusion of AF could be linked to the higher amount of grape must sugars. It is also relevant that a residual amount of sugars remained in the T3 experiment wines, as better discussed in the next paragraph. Temperature profiles regulated the $V_{\max }(n=6)$ of AF 


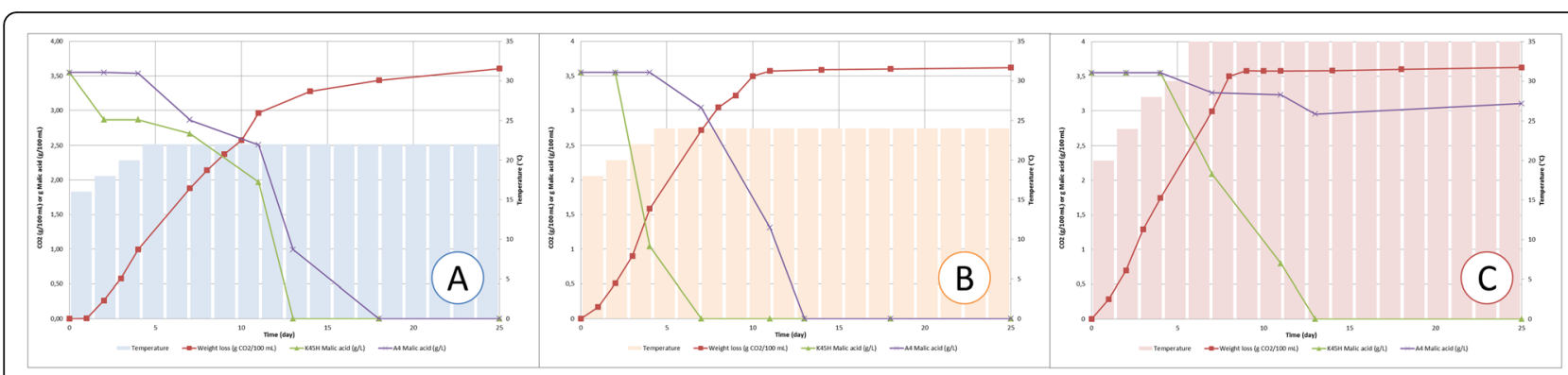

Fig. 1 Evolution of alcoholic and malolactic fermentation in function of different temperature profiles in grape must of $c v$. Chardonnay suitable for the production of sparkling wine (mean data, $n=6$ for AF and 3 for MLFs). a T1 test: $16 / 22^{\circ} \mathrm{C}$ in 3 days, $\mathbf{b}$ T2 test: $18 / 24{ }^{\circ} \mathrm{C}$ in 3 days, and $\mathbf{c}$ T3 test: $22 / 32^{\circ} \mathrm{C}$ in 5 days. The highest temperature profile interfered by the accomplishment of MLF by the 0 . oeni A4 strain

in experimental winemaking, reaching $2.7 \pm 0.1 \mathrm{~g} \mathrm{CO}_{2}$ $\mathrm{L}^{-1}$ day $^{-1}$ (T1), $3.9 \pm 0.3 \mathrm{~g} \mathrm{CO}_{2} \mathrm{~L}^{-1}$ day $^{-1}$ (T2), and $4.4 \pm 0.2 \mathrm{~g} \mathrm{CO}_{2} \mathrm{~L}^{-1}$ day $^{-1}$ (T3). The Lactobacillus strain confirmed its high efficiency in L-malic acid consumption. It required 5 days to consume the entire amount of L-malic acid independently of the temperature profiles (Fig. 2 a, b, and c). O. oeni A4 activity resulted more influenced by temperature profiles. The highest fermentation rate was obtained in T2 which concluded MLF in 9 days (Fig. $2 \mathrm{~b}, n=3$ ), in T1, malic degradation required 12 days (Fig. 1a, $n=3$ ) and, similarly to what was observed in the previous test, T3 (Fig. 2c, $n=3$ ) inhibited the activity of this bacteria residing in L-malic acid in wine at the end of the 30-day observation period.

\section{Evolution of microbial population}

The monitoring of the yeast population during AF by flow cytometry (Table 1) ensured information on cell density and its physiological state, differentiating between live, dead, and damaged cells depending on the permeability of the cell membrane and on cytoplasmic esterase activity (Guzzon and Larcher 2015). Yeast population growth dynamics appeared mostly influenced by the different temperatures and contributed toward explaining the data in Figs 1 and 2. In G1, no differences were observed in the yeast's dynamics in terms of the different strains of bacteria involved in the MLF; therefore, data were aggregated on the basis of the 3 temperature profiles tested (T1, T2, and T3 $n=6$ ). Two days after bacteria inoculum (day 4 , Table 1 ), experiment live cells in $\mathrm{T} 1$ reached $6.9 \pm 4.4 \log$ cell $/ \mathrm{mL}$ and the subpopulation represented by dead cells was negligible. In addition, no subpopulations of cells having a damaged membrane (Fig. 3a) were observed. At the end of experiments (day 18), live cells represented more than $98 \%$ of the yeast population. In the T2 test, yeast growth was more rapid, reaching $7.6 \pm 5.4 \log$ cell $/ \mathrm{mL}$ in 7 days (Table 1), but dead cells accounted for about $50 \%$ of the population on the 18th day of fermentation. Winemaking performed at $\mathrm{T} 3$ showed a concentration of yeast similar to that of $\mathrm{T} 2$ but cell decay was faster after 11 days of AF (Table 1). The differences observed in the ratio between live and dead cells at different temperature could be correlated at the different AF rate and, consequently, at long permanence of T2 and T3 yeast's population in starvation conditions (post AF). The determination of lactic bacteria concentration during MLF was carried out by plate count; therefore, only information on cells capable of growing on MRS medium

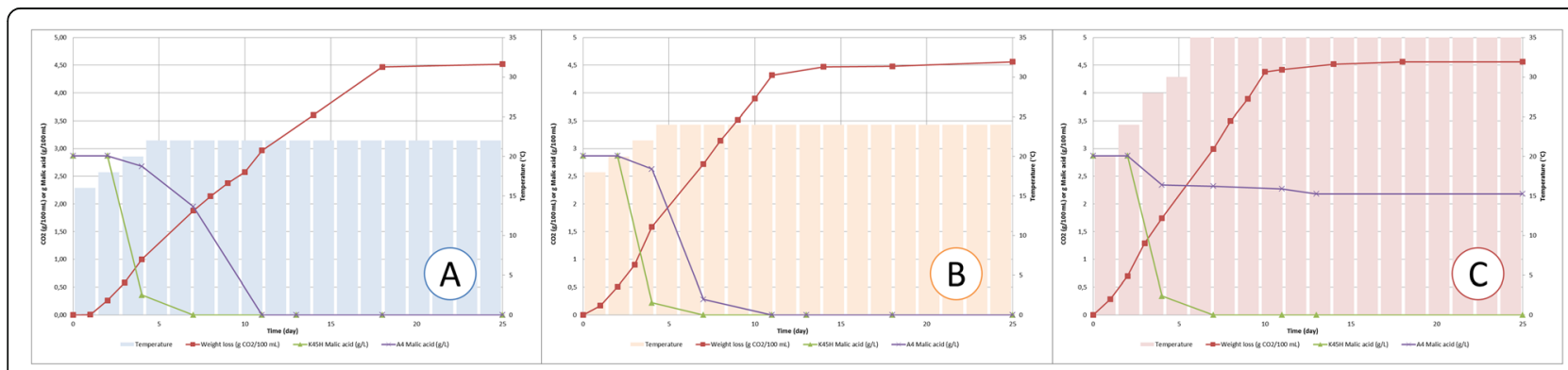

Fig. 2 Evolution of alcoholic and malolactic fermentation in function of different temperature profiles in grape must of $\mathrm{CV}$. Chardonnay harvested in full maturity (mean data, $n=6$ for AF and 3 for MLFs). a T1 test: $16 / 22{ }^{\circ} \mathrm{C}$ in 3 days, b T2 test: $18 / 24{ }^{\circ} \mathrm{C}$ in 3 days, and $\mathbf{c}$ T3 test: $22 / 32{ }^{\circ} \mathrm{C}$ in 5 days. The highest temperature profile interfered by the accomplishment of the AF, independently from the LAB strains, and with the MLF performed by the 0 . oeni A4 strain 
Table 1 Result of yeast (flow cytometric determination) and bacteria count (plate count onto MRS + TJ) performed during the 3 experimental winemaking. $\mathrm{T} 1$ test: $16 / 22{ }^{\circ} \mathrm{C}$ in 3 days, B. T2 test: $18 / 24^{\circ} \mathrm{C}$ in 3 days, and C. 13 test: $22 / 32{ }^{\circ} \mathrm{C}$ in 5 days. (Mean, $n=6$ in the case of yeast and $n=3$ in the case of LAB)

\begin{tabular}{|c|c|c|c|c|c|c|}
\hline \multirow[t]{2}{*}{ Microorganism } & \multirow{2}{*}{$\begin{array}{l}\text { Temperature } \\
\text { profile }\end{array}$} & \multicolumn{5}{|c|}{ Cell concentration (log units/mL) } \\
\hline & & Day 4 & Day 7 & Day 11 & Day 13 & Day 18 \\
\hline \multicolumn{7}{|l|}{ Grape must 1 (G1) } \\
\hline Yeast (live cells) & $\mathrm{T} 1$ & $6.9 \pm 4.4$ & $7.1 \pm 5.3$ & $6.8 \pm 5.4$ & $6.2 \pm 5.2$ & $5.4 \pm 4.2$ \\
\hline Yeast (dead cells) & $\mathrm{T} 1$ & nd & nd & $2.2 \pm 2.1$ & $2.7 \pm 2.2$ & $3.8 \pm 2.3$ \\
\hline Yeast (live cells) & $\mathrm{T} 2$ & $7.2 \pm 5.2$ & $7.6 \pm 5.4$ & $7.2 \pm 5.2$ & $6.8 \pm 5.4$ & $4.8 \pm 4.5$ \\
\hline Yeast (dead cells) & $\mathrm{T} 2$ & nd & nd & $2.4 \pm 1.2$ & $2.8 \pm 2.3$ & $3.6 \pm 2.4$ \\
\hline Yeast (live cells) & $\mathrm{T} 3$ & $7.3 \pm 5.2$ & $7.1 \pm 5.2$ & $6.9 \pm 5.2$ & $5.8 \pm 5.3$ & $4.4 \pm 4.2$ \\
\hline Yeast (dead cells) & $\mathrm{T} 3$ & $\mathrm{nr}$ & $2.8 \pm 1.4$ & $3.2 \pm 2.2$ & $4.5 \pm 3.1$ & $5.8 \pm 0.4$ \\
\hline A4 & $\mathrm{T} 1$ & $6.0 \pm 3.2$ & $6.1 \pm 4.5$ & $6.5 \pm 4.1$ & $6.5 \pm 4.7$ & $6.3 \pm 4.1$ \\
\hline A4 & $\mathrm{T} 2$ & $6.4 \pm 4.1$ & $6.5 \pm 4.9$ & $6.8 \pm 5.2$ & $6.9 \pm 5.3$ & $6.8 \pm 5.1$ \\
\hline A4 & $\mathrm{T} 3$ & $5.6 \pm 3.3$ & $5.5 \pm 4.2$ & $4.9 \pm 4.5$ & $4.9 \pm 3.9$ & nd \\
\hline $\mathrm{K} 45 \mathrm{H}$ & $\mathrm{T} 1$ & $6.1 \pm 3.7$ & $6.3 \pm 4.3$ & $6.6 \pm 3.9$ & $6.6 \pm 4.2$ & $6.2 \pm 4.1$ \\
\hline $\mathrm{K} 45 \mathrm{H}$ & $\mathrm{T} 2$ & $6.4 \pm 3.2$ & $6.4 \pm 4.7$ & $6.8 \pm 4.1$ & $6.5 \pm 4.2$ & $6.6 \pm 3.9$ \\
\hline $\mathrm{K} 45 \mathrm{H}$ & $\mathrm{T} 3$ & $5.9 \pm 3.3$ & $6.3 \pm 3.9$ & $6.4 \pm 4.2$ & $6.5 \pm 4.3$ & $6.3 \pm 4.4$ \\
\hline \multicolumn{7}{|l|}{ Grape must 2 (G2) } \\
\hline Yeast (live cells) & $\mathrm{T} 1$ & $7.0 \pm 5.2$ & $7.2 \pm 5.2$ & $7.1 \pm 5.7$ & $6.8 \pm 5.3$ & $5.8 \pm 4.4$ \\
\hline Yeast (dead cells) & $\mathrm{T} 1$ & nd & nd & $2.5 \pm 2.2$ & $2.7 \pm 2.1$ & $3.7 \pm 2.9$ \\
\hline Yeast (live cells) & $\mathrm{T} 2$ & $7.4 \pm 4.9$ & $7.8 \pm 6.2$ & $7.7 \pm 6.3$ & $6.9 \pm 5.9$ & $6.2 \pm 5.3$ \\
\hline Yeast (dead cells) & $\mathrm{T} 2$ & nd & $3.1 \pm 2.2$ & $3.3 \pm 2.4$ & $3.6 \pm 2.9$ & $3.9 \pm 3.1$ \\
\hline Yeast (live cells) & T3 & $7.1 \pm 5.3$ & $7.2 \pm 5.7$ & $6.0 \pm 5.1$ & $5.2 \pm 4.2$ & $4.9 \pm 4.5$ \\
\hline Yeast (dead cells) & $\mathrm{T} 3$ & nd & $2.9 \pm 2.4$ & $5.3 \pm 2.9$ & $5.4 \pm 3.3$ & $5.8 \pm 4.6$ \\
\hline A4 & $\mathrm{T} 1$ & $5.5 \pm 4.1$ & $5.4 \pm 4.3$ & $5.8 \pm 4.2$ & $5.7 \pm 4.4$ & $5.6 \pm 4.3$ \\
\hline A4 & $\mathrm{T} 2$ & $6.5 \pm 5.2$ & $6.6 \pm 5.1$ & $6.9 \pm 5.2$ & $7.0 \pm 6.1$ & $6.9 \pm 5.8$ \\
\hline A4 & $\mathrm{T} 3$ & $5.5 \pm 4.2$ & $5.5 \pm 4.3$ & nd & nd & nd \\
\hline $\mathrm{K} 45 \mathrm{H}$ & $\mathrm{T} 1$ & $6.5 \pm 5.2$ & $6.9 \pm 5.3$ & $6.9 \pm 5.2$ & $6.6 \pm 5.1$ & $6.7 \pm 5.4$ \\
\hline $\mathrm{K} 45 \mathrm{H}$ & $\mathrm{T} 2$ & $6.6 \pm 5.3$ & $6.6 \pm 6.1$ & $7.0 \pm 6.4$ & $6.7 \pm 5.3$ & $6.8 \pm 5.1$ \\
\hline $\mathrm{K} 45 \mathrm{H}$ & T3 & $6.0 \pm 5.3$ & $6.1 \pm 5.3$ & $6.6 \pm 5.2$ & $6.1 \pm 5.9$ & $6.2 \pm 5.2$ \\
\hline
\end{tabular}

were available (Table 1). In G1 experiments, L. plantarum $\mathrm{K} 45 \mathrm{H}$ was characterized by the highest cellular density in the first days after inoculum in grape must, while the $O$ oeni A4 strain reached its maximum concentration later. The differences observed in terms of bacterial density are not relevant from a technological point of view and microbial load were generally sufficient to ensure an efficient MLF (Lonvaud-Funel 1999; Liu 2002). In tests performed at $\mathrm{T} 2$, the L. plantarum $\mathrm{K} 45 \mathrm{H}$ strain reached $6.8 \pm 4.8 \log \mathrm{CFU} / \mathrm{mL}(n=3)$ after 11 days, while the $O$. oeni A4 strains grew to $6.9 \pm 4.9$ $\log$ CFU/mL $(n=3)$ after 13 days of AF. T1 and T3 experiments showed poorer performance in terms of maximum bacterial concentration for the two bacterial strains, not passing $6.6 \log \mathrm{CFU} / \mathrm{mL}$ in the case of the Lactobacillus strain (T1, G1, Table 2) and 6.5 log CFU/ $\mathrm{mL}$ in the case of the O. oeni strain (T1, G1, Table 2). It is worth noting that in the T3 experiments O. oeni A4 decreases below $5 \log$ units 11 days after the inoculum. This sudden mortality explains the incomplete L-malic degradation observed in this test.

Yeast populations in experiments G2 made at T1 and T2 grew quickly, after a lag-phase of $24 \mathrm{~h}$, up to a cell density of $7 \mathrm{log}$ units. The T1 test showed a live yeast concentration of $7.2 \pm 5.9 \log$ cell $/ \mathrm{mL}(n=3)$ on the 7 th day (Table 1 ), with a negligible presence of dead cells; live cells represented more than $90 \%$ of the yeast population for the test's entire duration. T2 data are similar to the previous ones, with a maximum cell load of $7.8 \pm 6.2$ $(n=3) \log$ cell $/ \mathrm{mL}$ at day 7 . On the contrary, in the T3 experiment, after the yeast population's initial growth, a rapid decline in the cellular vitality was observed (Fig. 3) which reduced the population of $S$. cerevisiae below the critical value of $6 \log$ cell/mL 11 days after the beginning 

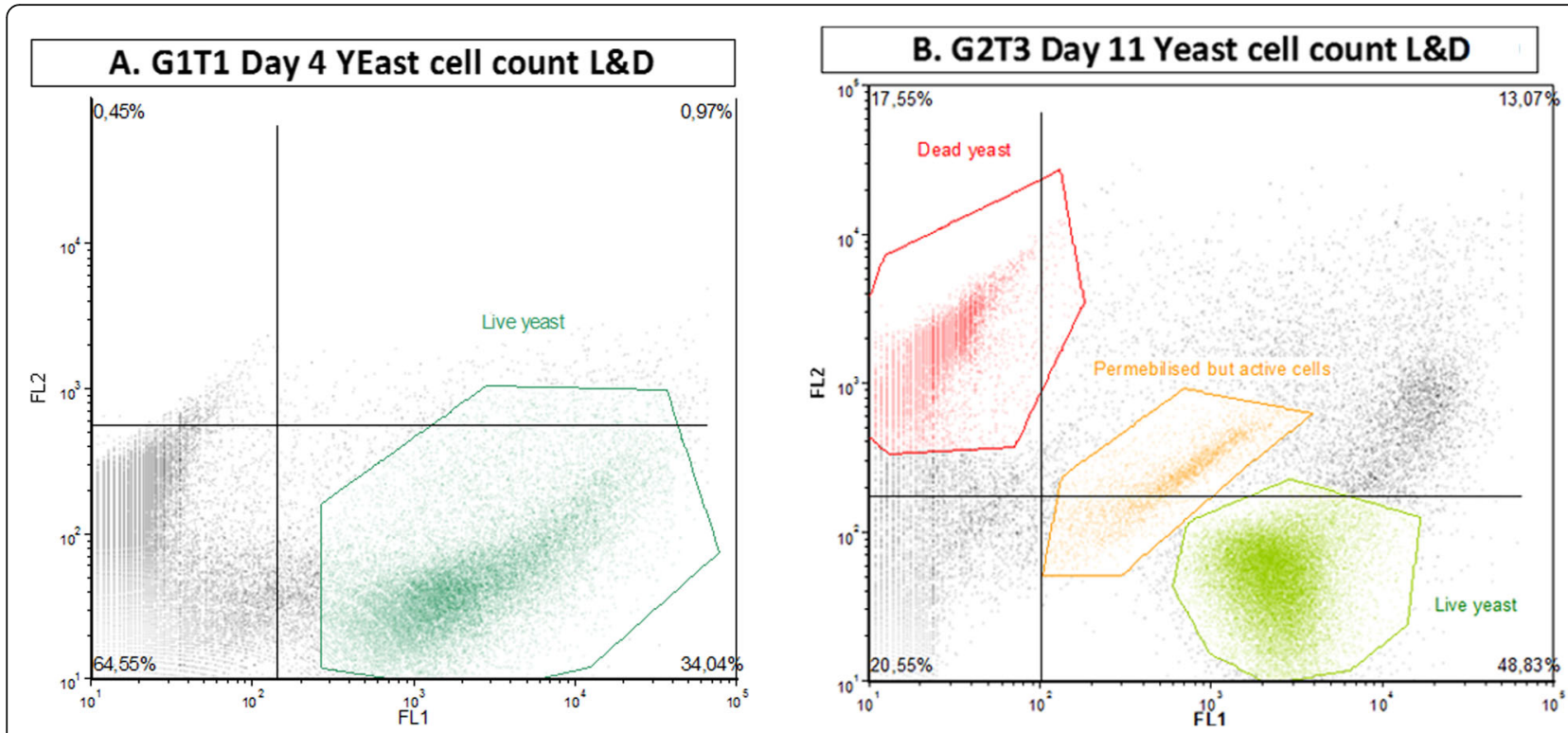

Fig. 3 Flow cytometric assay of yeast population observed during alcoholic fermentation. a Yeast population of G1T1 experiment after 4 days from the inoculum. $\mathbf{b}$ Yeast population of G2T3 experiment observed 11 days after the beginning of AF

of the test (Table 1). This dynamic resulted in an arrest in sugar degradation and in their residue in wine above $30 \mathrm{~g} / \mathrm{L}$, as we will discuss in the next paragraph. The evolution of the bacterial population of the G2 experiments are similar to G1, with the difference that the lower acidity of the second grape must favored bacterial growth (Table 2). L. plantarum $\mathrm{K} 45 \mathrm{H}$ showed a concentration of $7.0 \pm 6.4 \log \mathrm{CFU} / \mathrm{mL}$ after 7 days, a similar value of microbial load was reached by the O. oeni A4 strain in 11 days. However, in the T1 and T2 tests, the bacterial population's evolution showed a progressive adaptation to these specific environmental conditions with a relevant cell growth with respect to the initial inoculum, maintaining cellular load up to $6 \log \mathrm{CFU}$ for the entire duration of MLF. The highest temperature profile (T3, Table 2) appeared detrimental because

Table 2 Chemical parameters of wines obtained by simultaneous fermentation of S. cerevisiae and $L$. plantarum or $O$. oeni at different temperature profiles. $\mathrm{T} 1$ test: $16 / 22{ }^{\circ} \mathrm{C}$ in 3 days, B. T2 test: $18 / 24{ }^{\circ} \mathrm{C}$ in 3 days, and C. T3 test: $22 / 32{ }^{\circ} \mathrm{C}$ in 5 days. (Mean, $n=3$ ). * Differences are statistically significant both in terms of bacteria strain and temperature profile effect (two-way ANOVA test, $p=0.05$ ). ${ }^{\circ}$ Differences are statistically significant in terms of temperature effect (two-way ANOVA test, $p=0.05$ )

\begin{tabular}{|c|c|c|c|c|c|c|c|c|c|c|}
\hline $\begin{array}{l}\text { Bacteria } \\
\text { strain }\end{array}$ & $\begin{array}{l}\text { Grape must/temperature } \\
\text { profile }\end{array}$ & Ethanol & $\mathrm{pH}$ & $\begin{array}{l}\text { Tot. acidity (as tartaric } \\
\text { acid) }\end{array}$ & $\begin{array}{l}\text { Acetic } \\
\text { acid }\end{array}$ & $\begin{array}{l}\text { Glucose and } \\
\text { fructose }\end{array}$ & $\begin{array}{l}\text { Tartaric } \\
\text { acid }\end{array}$ & $\begin{array}{l}\text { Malic } \\
\text { acid }\end{array}$ & $\begin{array}{l}\text { Lactic } \\
\text { acid }\end{array}$ & Glycerol \\
\hline
\end{tabular}

(\% vol) g/L

Grape must 1 (G1)

$\begin{array}{lllll}\text { A4 } & \text { T1 } & 11.4^{*} & 3.25^{*} & 3.6^{\circ} \\ \text { A4 } & \text { T2 } & 11.3^{*} & 3.24^{*} & 3.9^{\circ} \\ \text { A4 } & \text { T3 } & 10.9^{*} & 3.07^{*} & 5.4^{\circ} \\ \text { KA5 H } & \text { T1 } & 11.4^{*} & 3.19^{*} & 4.3^{\circ} \\ \text { KA5 H } & \text { T2 } & 11.3^{*} & 3.15^{*} & 4.4^{\circ} \\ \text { KA5 H } & \text { T3 } & 11.2^{*} & 3.17^{*} & 4.3^{\circ}\end{array}$

$\begin{array}{llllll}0.15^{\circ} & <1.0 & 1.58^{*} & <0.35^{\circ} & 2.15^{*} & 4.7^{*} \\ 0.22^{\circ} & <1.0 & 1.59^{*} & <0.35^{\circ} & 2.20^{*} & 5.2^{*} \\ <0.10^{\circ} & 3.0^{*} & 1.69^{*} & 2.98^{\circ} & <0.50^{*} & 5.5^{*} \\ 0.12^{\circ} & <1.0 & 1.64^{*} & <0.35^{\circ} & 3.00^{*} & 4.2^{*} \\ 0.17^{\circ} & <1.0 & 1.77^{*} & <0.35^{\circ} & 2.94^{*} & 4.9^{*} \\ 0.10^{\circ} & <1.0 & 1.70^{*} & <0.35^{\circ} & 2.47^{*} & 5.3^{*}\end{array}$

Grape must 2 (G2)

\begin{tabular}{lllll} 
A4 & T1 & $13.8^{*}$ & $3.57^{*}$ & $3.0^{\circ}$ \\
A4 & T2 & $13.8^{*}$ & $3.60^{*}$ & $3.4^{\circ}$ \\
A4 & T3 & $11.4^{*}$ & $3.49^{*}$ & $4.5^{\circ}$ \\
KA5 H & T1 & $13.7^{*}$ & $3.54^{*}$ & $3.2^{\circ}$ \\
KA5 H & T2 & $13.8^{*}$ & $3.55^{*}$ & $3.6^{\circ}$ \\
KA5 H & T3 & $11.7^{*}$ & $3.51^{*}$ & $3.8^{\circ}$ \\
\hline
\end{tabular}

$\begin{array}{ll}0.26^{*} & 2.7^{*} \\ 0.30^{*} & 2.7^{*} \\ 0.60^{*} & 35.6^{*} \\ 0.23^{*} & 2.1^{*} \\ 0.27^{*} & 2.9^{*} \\ 0.32^{*} & 30.1^{*}\end{array}$

$1.07^{*}$

$<0.35^{\circ} \quad 1.67^{*} \quad 6.3^{*}$

$<0.35^{\circ} \quad 1.81^{*} \quad 7.4^{*}$

$2.68^{\circ}<0.50^{*} \quad 7.4^{*}$

$<0.35^{\circ} \quad 1.63^{*} \quad 6.1^{*}$

$<0.35^{\circ} \quad 1.98^{*} \quad 7.2^{*}$ 
bacterial concentration remained below $6.6 \log \mathrm{CFU} / \mathrm{mL}$ in the case of $\mathrm{K} 45 \mathrm{H}$, and below $5 \log \mathrm{CFU} / \mathrm{mL}$ for $O$. oeni A4, which was not detectable 11 days after the beginning of the experiments.

\section{Influence of temperature profiles on the chemical composition of wines}

Table 2 lists the main chemical parameters of wines obtained by the simultaneous fermentation of yeast and bacteria at different temperature profiles. Wines resulting from $\mathrm{G} 1$ and fermented by $L$. plantarum $\mathrm{K} 45 \mathrm{H}$ did not show differences in their composition in terms of the main oenological features. Alcoholic and malolactic fermentations were accomplished with the complete consumption of sugars $(<0.1 \mathrm{~g} / \mathrm{L})$ and Lmalic acid $(<0.35 \mathrm{~g} / \mathrm{L})$. Volatile acidity reached a mean concentration $(n=9)$ of $0.13 \pm 0.03 \mathrm{~g} / \mathrm{L}$, a value that can be considered negligible in winemaking. The wines obtained by $\mathrm{O}$. oeni A4 at T1 and T2 (Table 3) showed a similar composition to the former, with the exception of a lower conversion yield of malic acid to lactic acid. Its concentration was about $0.8 \mathrm{~g} / \mathrm{L}$ lower than in wines where MLF was performed with $L$. plantarum. This difference is also reflected in the $\mathrm{pH}$, which is slightly higher, and could be related to a partial consumption of malic acid by yeasts (Su et al. 2014). Indeed, T3 evidenced a residual content of sugars (Table 2) and the absence of consumption of the malic acid which resided in wines (mean $2.98 \pm 0.12 \mathrm{~g} / \mathrm{L}, n=3$ ). Volatile acidity (mean $0.13 \pm 0.04 \mathrm{~g} / \mathrm{L}, n=9$ ) and ethanol content (mean $11.2 \pm 0.6 \% \mathrm{v} / \mathrm{v}, n=9$ ) did not differ significantly from those of wines made by L. plantarum $\mathrm{K} 45 \mathrm{H}$. Wine obtained from G2 by the two bacterial strains at T1 and T2 have a similar chemical composition (Table 3 ). The stress observed in the microbial population (Table 1) in G2T3 resulted in an alteration in the chemical profile of obtained wines. In the case of the experiment performed by L. plantarum $\mathrm{K} 45 \mathrm{H}, 30.1 \pm 0.3 \mathrm{~g} / \mathrm{L}(n=3)$ of sugars resided in wines, causing a loss in ethanol accumulation of about 2\% (Table 3). In the case of trials performed by $O$. oeni A4, the lack of sugar consumption $(35.4 \pm 0.6 \mathrm{~g} / \mathrm{L}, n$ $=3)$ is accompanied by MLF failure $(2.61 \pm 0.02 \mathrm{~g} / \mathrm{L}$ of Lmalic acid, $n=3$ ) and by the increase in volatile acidity $(0.60 \pm 0.07 \mathrm{~g} / \mathrm{L}, n=3)$. The statistical analysis of data (two-way ANOVA test, Table 2) underlines that both variables considered (temperature profile and LAB strain) influence the variability of the majority of the enological parameters. Regarding the variations in the acidic profile, in particular in acetic and malic acid concentration, the temperature is the only statistically significant variable. Some hypothesis about the effect of the high temperature on the metabolism of the two microbial populations will be discussed in the next chapter.
The volatile profiles of the wines were determined by GC-MS, taking 71 molecules into consideration, of which 51 resulted quantifiable in at least one sample (Table 3). Gas chromatographic analysis detected 38 free volatile compounds and revealed differences in the set of data in terms of the degree of ripeness of grapes (G1 or G2). However, the technological variables considered (temperature and strain of LAB) resulted relevant in driving the evolution of the wines' volatile profile. According to the features of $c v$. Chardonnay, which contains less concentration of volatile precursors, esters (ethyl lactate and other ethylic esters), higher alcohols (1-hexanol and 2-phenyl ethanol), and fatty acids (hexanoic acid, octanoic acid, and decanoic acid) dominated the aromatic profile of the wines. Temperature proved to be the most significant variable (two-way ANOVA test, Table 3), influencing the content of $47 \%$ of the volatile compounds, while the differences between the two strains were found to be relevant only in the $18 \%$ of cases. Finally, the cooperative interaction of both variables was observed significant in 4 compounds $(7 \%$ of the aromatic profile, Table 3). In details, the test performed by $\mathrm{O}$. oeni A4, the differences among $\mathrm{T} 1$ and $\mathrm{T} 2$ data are included in the variability observed in the different replicates. To the contrary, the highest fermentation temperature (T3) reduces the content of esters and fatty acids, thus increasing the presence of higher alcohols (Table 3). By contrast, L. plantarum $\mathrm{K} 45 \mathrm{H}$ proportionally accumulated esters at fermentation temperature, with a similar trend observed for 2-phenyl ethanol. In the tests with $O$. oeni the increase in temperature reduced the concentration of fatty acids, independently of the length of the carboxylic chain. The analysis of bound volatile compounds allowed the quantification of 13 molecules with relevant differences between the wines obtained from the two grape musts although, in general, the quantities of these compounds are very low. Benzyl alcohol is the most represented compound from among bonded molecules in G1. We observed its increases in T3 with respect to the other two fermentation temperature profiles and this trend appeared independent of the LAB strain involved in MLF. In G2, GC-MS quantified a small amount of terpins, whose accumulation is probably favored by the advanced ripeness of the grapes (Gambetta et al. 2016). These molecules did not vary as a function of the fermentation temperature or the LAB strain. Similar results were observed for 2phenyl ethanol and benzyl alcohol, as the most represented bounded volatile compounds in G2: the different variables of the experiments did not alter their concentration.

A PCA analysis was performed (Fig. 4) considering the 20 volatile compounds having the highest concentration among free volatiles in order to verify the 
Table 3 Profile of free and bounded volatile compounds, determined by GC-MS, of wines obtained by simultaneous fermentation of S. cerevisiae and L. plantarum or O. oeni at different temperature profiles. T1 test: $16 / 22{ }^{\circ} \mathrm{C}$ in 3 days, B. T2 test: $18 / 24{ }^{\circ} \mathrm{C}$ in 3 days, and C. T3 test: $22 / 32{ }^{\circ} \mathrm{C}$ in 5 days. ${ }^{\circ}$ Differences are statistically significant both in terms of bacteria strain and temperature profile effect (two-way ANOVA test, $p=0.05$ ). Differences are statistically significant in terms of temperature effect (two-way ANOVA test, $p=0.05$ ). *Differences are statistically significant in terms of strain effect (two-way ANOVA test, $p=0.05$ )

\begin{tabular}{|c|c|c|c|c|c|c|c|c|c|c|c|c|}
\hline$\angle A B$ & A4 & A4 & A4 & $\mathrm{K} 45 \mathrm{H}$ & $\mathrm{K} 45 \mathrm{H}$ & $\mathrm{K} 45 \mathrm{H}$ & A4 & A4 & A4 & $\mathrm{K} 45 \mathrm{H}$ & $\mathrm{K} 45 \mathrm{H}$ & $\mathrm{K} 45 \mathrm{H}$ \\
\hline Temp. profile & $\mathrm{T} 1$ & $\mathrm{~T} 2$ & T3 & $\mathrm{T1}$ & $\mathrm{T} 2$ & $\mathrm{~T} 3$ & $\mathrm{T1}$ & T2 & T3 & $\mathrm{T1}$ & $\mathrm{T} 2$ & T3 \\
\hline Grape must & \multicolumn{6}{|c|}{ G1 (early harvest) } & \multicolumn{6}{|c|}{ G2 (late harvest) } \\
\hline \multicolumn{13}{|l|}{ Free compound (mg/L) } \\
\hline n-butyl acetate ${ }^{\circ}$ & 0.002 & 0.004 & 0.005 & 0.004 & 0.002 & 0.001 & 0.002 & 0.003 & 0.002 & 0.002 & 0.002 & 0.003 \\
\hline n-hexyl acetate & 0.069 & 0.056 & 0.055 & 0.086 & 0.057 & 0.060 & 0.053 & 0.051 & 0.038 & 0.055 & 0.055 & 0.036 \\
\hline Isobutyl acetate & 0.007 & 0.009 & 0.014 & 0.007 & 0.010 & 0.015 & 0.014 & 0.025 & 0.032 & 0.015 & 0.028 & 0.024 \\
\hline Isopentyl acetate & 0.213 & 0.216 & 0.234 & 0.262 & 0.200 & 0.238 & 0.925 & 1.072 & 0.690 & 0.927 & 1.152 & 0.588 \\
\hline Ethyl butyrate & 0.072 & 0.056 & 0.032 & 0.086 & 0.062 & 0.036 & 0.207 & 0.171 & 0.066 & 0.221 & 0.172 & 0.060 \\
\hline Ethyl hexanoate ${ }^{\circ *} *$ & 0.255 & 0.166 & 0.077 & 0.332 & 0.198 & 0.088 & 0.592 & 0.471 & 0.141 & 0.678 & 0.493 & 0.151 \\
\hline Ethyl octanoate & 0.288 & 0.187 & 0.078 & 0.339 & 0.194 & 0.114 & 0.820 & 0.702 & 0.177 & 0.873 & 0.676 & 0.239 \\
\hline Ethyl decanoate & 0.106 & 0.116 & 0.040 & 0.131 & 0.096 & 0.051 & 0.204 & 0.179 & 0.077 & 0.256 & 0.189 & 0.126 \\
\hline Ethyl dodecanoate & 0.006 & 0.066 & 0.006 & 0.006 & 0.005 & 0.006 & 0.024 & 0.020 & 0.013 & 0.036 & 0.025 & 0.017 \\
\hline Diethyl-succinate ${ }^{0 * *}$ & 0.014 & 0.035 & 0.078 & 0.010 & 0.025 & 0.055 & 0.033 & 0.072 & 0.090 & 0.028 & 0.068 & 0.058 \\
\hline 2-phenylethyl acetate* & 0.083 & 0.094 & 0.101 & 0.073 & 0.081 & 0.099 & 0.335 & 0.391 & 0.244 & 0.303 & 0.369 & 0.217 \\
\hline Ethyl phenyl acetate & 0.000 & 0.000 & 0.003 & 0.000 & 0.001 & 0.001 & 0.000 & 0.000 & 0.000 & 0.000 & 0.000 & 0.000 \\
\hline Ethyl lactate $e^{0^{\star *}}$ & 21.603 & 24.278 & 3.797 & 16.528 & 23.206 & 30.025 & 11.449 & 10.732 & 3.536 & 6.034 & 10.447 & 16.649 \\
\hline 1-hexanol & 1.162 & 1.101 & 1.126 & 1.182 & 1.194 & 1.030 & 0.377 & 0.364 & 0.344 & 0.373 & 0.380 & 0.331 \\
\hline Trans-3-hexen-1ol & 0.033 & 0.033 & 0.034 & 0.034 & 0.035 & 0.033 & 0.028 & 0.030 & 0.028 & 0.030 & 0.031 & 0.027 \\
\hline cis-3-hexen-1ol & 0.019 & 0.018 & 0.018 & 0.020 & 0.019 & 0.018 & 0.026 & 0.025 & 0.023 & 0.027 & 0.028 & 0.024 \\
\hline 2-phenylethanol ${ }^{\star}$ & 10.085 & 12.504 & 20.358 & 9.626 & 13.464 & 16.143 & 18.593 & 24.247 & 20.009 & 18.107 & 23.057 & 17.857 \\
\hline Benzyl alcohol ${ }^{\wedge *}$ & 0.183 & 0.214 & 0.119 & 0.353 & 0.517 & 0.124 & 0.081 & 0.084 & 0.039 & 0.132 & 0.161 & 0.095 \\
\hline Butanoic acid ${ }^{\star}$ & 0.363 & 0.504 & 0.286 & 0.438 & 0.406 & 0.275 & 0.776 & 0.710 & 0.437 & 0.754 & 0.648 & 0.372 \\
\hline Isobutyric acid & 0.152 & 0.245 & 0.186 & 0.122 & 0.151 & 0.175 & 0.134 & 0.175 & 0.197 & 0.162 & 0.161 & 0.161 \\
\hline Valeric acid & 0.037 & 0.017 & 0.014 & 0.013 & 0.017 & 0.017 & 0.015 & 0.016 & 0.020 & 0.012 & 0.016 & 0.019 \\
\hline Isovaleric acid & 0.108 & 0.175 & 0.168 & 0.111 & 0.140 & 0.139 & 0.186 & 0.197 & 0.202 & 0.181 & 0.204 & 0.170 \\
\hline Hexanoic acid ${ }^{`}$ & 2.449 & 2.249 & 1.212 & 3.234 & 2.338 & 1.254 & 5.586 & 4.922 & 1.985 & 6.363 & 5.004 & 2.083 \\
\hline Octanoic acid & 1.875 & 1.395 & 1.008 & 2.437 & 1.593 & 0.976 & 4.701 & 4.682 & 2.137 & 5.482 & 4.783 & 2.334 \\
\hline Nonanoic acid & 0.142 & 0.026 & 0.014 & 0.005 & 0.007 & 0.008 & 0.005 & 0.005 & 0.003 & 0.007 & 0.004 & 0.009 \\
\hline Decanoic acid ${ }^{\star}$ & 1.451 & 0.811 & 0.891 & 1.652 & 1.314 & 0.824 & 2.662 & 2.772 & 1.616 & 3.436 & 2.999 & 1.953 \\
\hline Linalol oxide A* & 0.001 & 0.000 & 0.002 & 0.000 & 0.000 & 0.001 & 0.007 & 0.006 & 0.007 & 0.005 & 0.006 & 0.007 \\
\hline Linalol oxide B ${ }^{\star}$ & 0.001 & 0.000 & 0.002 & 0.000 & 0.000 & 0.001 & 0.004 & 0.004 & 0.005 & 0.004 & 0.004 & 0.004 \\
\hline Linalool` $^{\star}$ & 0.002 & 0.003 & 0.004 & 0.001 & 0.003 & 0.005 & 0.000 & 0.002 & 0.003 & 0.003 & 0.002 & 0.002 \\
\hline Geranic acid & 0.240 & 0.045 & 0.027 & 0.004 & 0.006 & 0.000 & 0.000 & 0.000 & 0.000 & 0.000 & 0.000 & 0.000 \\
\hline Methyl salycilate* & 0.005 & 0.002 & 0.001 & 0.000 & 0.000 & 0.000 & 0.001 & 0.001 & 0.000 & 0.000 & 0.001 & 0.000 \\
\hline Benzaldehyde & 0.008 & 0.007 & 0.004 & 0.034 & 0.012 & 0.016 & 0.018 & 0.016 & 0.004 & 0.009 & 0.021 & 0.012 \\
\hline Zingerone & 0.092 & 0.011 & 0.007 & 0.003 & 0.003 & 0.001 & 0.000 & 0.001 & 0.000 & 0.002 & 0.002 & 0.000 \\
\hline Guaiacol & 0.008 & 0.002 & 0.002 & 0.001 & 0.002 & 0.003 & 0.002 & 0.002 & 0.002 & 0.002 & 0.002 & 0.002 \\
\hline 3-methylthio-1-propanol** & 0.304 & 0.378 & 0.509 & 0.284 & 0.384 & 0.483 & 0.288 & 0.352 & 0.542 & 0.228 & 0.331 & 0.304 \\
\hline Benzothiazole & 0.005 & 0.003 & 0.005 & 0.002 & 0.003 & 0.005 & 0.002 & 0.003 & 0.005 & 0.002 & 0.003 & 0.007 \\
\hline Methyl antranilate* & 0.015 & 0.004 & 0.003 & 0.000 & 0.001 & 0.000 & 0.000 & 0.000 & 0.000 & 0.000 & 0.000 & 0.000 \\
\hline Ethyl antranilate* & 0.019 & 0.005 & 0.004 & 0.001 & 0.002 & 0.000 & 0.000 & 0.000 & 0.000 & 0.000 & 0.000 & 0.000 \\
\hline
\end{tabular}


Table 3 Profile of free and bounded volatile compounds, determined by GC-MS, of wines obtained by simultaneous fermentation of S. cerevisiae and L. plantarum or O. oeni at different temperature profiles. T1 test: $16 / 22{ }^{\circ} \mathrm{C}$ in 3 days, B. T2 test: $18 / 24{ }^{\circ} \mathrm{C}$ in 3 days, and C. T3 test: $22 / 32{ }^{\circ} \mathrm{C}$ in 5 days. ${ }^{\circ}$ Differences are statistically significant both in terms of bacteria strain and temperature profile effect (two-way ANOVA test, $p=0.05$ ). Differences are statistically significant in terms of temperature effect (two-way ANOVA test, $p=0.05$ ). *Differences are statistically significant in terms of strain effect (two-way ANOVA test, $p=0.05$ ) (Continued)

\begin{tabular}{|c|c|c|c|c|c|c|c|c|c|c|c|c|}
\hline$\overline{L A B}$ & A4 & A4 & A4 & $\mathrm{K} 45 \mathrm{H}$ & $\mathrm{K} 45 \mathrm{H}$ & $\mathrm{K} 45 \mathrm{H}$ & A4 & A4 & A4 & $\mathrm{K} 45 \mathrm{H}$ & $\mathrm{K} 45 \mathrm{H}$ & $\mathrm{K} 45 \mathrm{H}$ \\
\hline \multicolumn{13}{|c|}{ Bound compound $(\mathrm{mg} / \mathrm{L})$} \\
\hline 1-hexanol ${ }^{\wedge}$ & 0.025 & 0.025 & 0.038 & 0.031 & 0.030 & 0.031 & 0.056 & 0.051 & 0.054 & 0.052 & 0.052 & 0.052 \\
\hline trans-3-hexen-1ol & 0.000 & 0.000 & 0.001 & 0.000 & 0.000 & 0.000 & 0.002 & 0.002 & 0.002 & 0.002 & 0.002 & 0.002 \\
\hline cis-3-hexen-10/ ${ }^{\wedge}$ & 0.004 & 0.004 & 0.006 & 0.004 & 0.005 & 0.004 & 0.018 & 0.016 & 0.018 & 0.018 & 0.016 & 0.017 \\
\hline 2-phenylethanol ${ }^{\star \star}$ & 0.123 & 0.131 & 0.183 & 0.136 & 0.144 & 0.176 & 0.392 & 0.366 & 0.383 & 0.326 & 0.363 & 0.343 \\
\hline Benzyl alcohol & 1.219 & 1.382 & 1.798 & 1.447 & 1.518 & 2.052 & 2.166 & 1.763 & 1.695 & 1.779 & 1.944 & 1.942 \\
\hline Linalol oxide A & 0.000 & 0.000 & 0.000 & 0.000 & 0.000 & 0.000 & 0.003 & 0.004 & 0.004 & 0.004 & 0.004 & 0.004 \\
\hline Linalol oxide B` & 0.000 & 0.000 & 0.000 & 0.000 & 0.000 & 0.000 & 0.002 & 0.002 & 0.002 & 0.002 & 0.002 & 0.001 \\
\hline Nerol & 0.000 & 0.000 & 0.000 & 0.000 & 0.000 & 0.000 & 0.001 & 0.002 & 0.002 & 0.002 & 0.002 & 0.002 \\
\hline Geraniol & 0.000 & 0.000 & 0.000 & 0.000 & 0.000 & 0.000 & 0.003 & 0.003 & 0.003 & 0.003 & 0.003 & 0.003 \\
\hline Geranic acid & 0.000 & 0.000 & 0.001 & 0.000 & 0.005 & 0.000 & 0.004 & 0.000 & 0.004 & 0.003 & 0.004 & 0.004 \\
\hline Benzaldehyde & 0.013 & 0.015 & 0.012 & 0.012 & 0.016 & 0.012 & 0.017 & 0.013 & 0.010 & 0.014 & 0.012 & 0.013 \\
\hline Methyl salycilate & 0.002 & 0.002 & 0.002 & 0.002 & 0.002 & 0.002 & 0.004 & 0.005 & 0.006 & 0.005 & 0.006 & 0.006 \\
\hline Zingerone & 0.001 & 0.002 & 0.003 & 0.001 & 0.004 & 0.003 & 0.001 & 0.002 & 0.003 & 0.000 & 0.001 & 0.002 \\
\hline
\end{tabular}

capacity of the technological variables and the composition of grape musts to differentiate the volatile profile of the wines obtained. This choice is designed to simplify data analysis considering that the PCA analysis on the entire set of data does not differ (data not shown). Figure 4 a portrays the spatial distribution of the variables on the plane defined by factors 1 and 2, explaining $78.21 \%$ of total variability, while Fig. $4 \mathrm{~b}$ shows the spatial distribution of the wine samples. The volatile compound profile distinguishes wines belonging to the two different grape musts, particularly due to the higher concertation of bounded compounds that characterized G2. Among the two technological variables considered in this
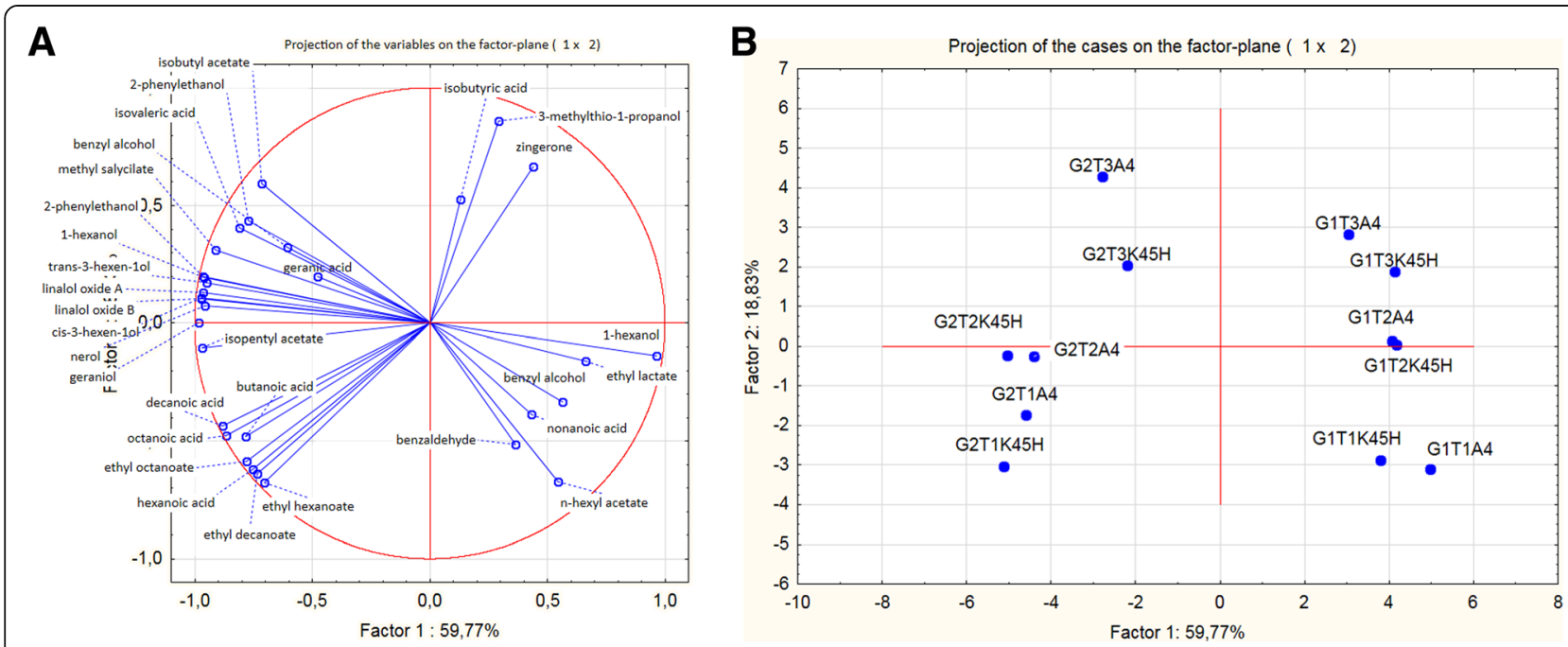

Fig. 4 PCA analysis of the main represented volatile compounds that characterized wines obtained by yeast/bacteria simultaneous fermentation at different temperature profiles (mean data, $n=3$ ). Experiments were performed in two different grape must (G1 and G2) at 3 temperature profiles. $\mathrm{T} 1$ test: $16 / 22^{\circ} \mathrm{C}$ in 3 days, B. $T 2$ test: $18 / 24^{\circ} \mathrm{C}$ in 3 days, and $\mathbf{C}$. $T 3$ test: $22 / 32{ }^{\circ} \mathrm{C}$ in 5 days. a Projection of variables in the plain $1 \times 2 . \mathbf{b}$ Distribution of cases in the plain $1 \times 2$ 
work, the temperature profile appears to be more capable of distinguishing between the different samples than the bacterial strains. In the G1 experiments, wine made from the lowest fermentation temperature (G1T1, Fig. 4) resulted clearly separated to that obtained at T2 and T3, independently of the LAB strain. To the contrary, in G2 based tests, the wine obtained at T3 is segregated from the others. The reasons for the distribution of cases in the PCA analysis could be found in the microbial population evolution described above and in the resulting different volatile compound profile, as discussed in the next part of the work.

\section{Discussion}

The addition of bacteria to grape must during AF to obtain quick MLF is a practice that has gained increasing interest among winemakers. The reasons of this trend have already been discussed in the first chapter of the work. To summarize, the improved microbiological control that the simultaneous fermentation ensured, is correlated to the unique organoleptic profile of wines derived from this winemaking approach (Jussier et al. 2006, Guzzon et al. 2013). The simultaneous presence of two high-concentration microbe populations, yeast and bacteria, in the same environment does not frequently occur in winemaking. Usually, the bio-transformation of grape must in wine drives the evolution of microflora due to the progressive disappearance of essential substrates (sugars and nitrogen compounds) and the accumulation of toxic agents, such as ethanol and $\mathrm{SO}_{2}$. This environmental evolution selects the oenological microflora (Barata et al. 2012). LAB is able to develop after glucose and fructose depletion, when the more vigorous S. cerevisiae disappears (Liu 2002, Alexandre et al. 2004, Lonvaud-Funel 1999). The interaction between yeast and bacteria during winemaking has been already studied, identifying molecules released by yeast that are capable of repressing LAB activity (Alexandre et al. 2004). In addition, Costello et al. (2003) have underlined the importance of a careful choice of the yeast-bacterial pair to avoid inhibition of MLF. In this work, the yeast strain Lalvin ICV D47 was chosen because no negative interactions with the two lactic bacteria strains involved in the experiments are known. However, observing the results of this work, it is hypothisable that the response of microorganisms to the environmental stress, including non-ideal fermentation temperatures, is influenced by the competition between different microbial populations that can develop together.

In the first grape must (G1), which has a low sugar concentration and consequently, low potential alcohol content, S. cerevisiae does not apparently experience bacterial competition resulting in the regular evolution of AFs (Fig. 1). This behavior is consistent with those of previous works concerning the interaction between yeast and bacteria during oenological fermentations (Alexandre et al. 2004; Jussier et al. 2006; Guzzon et al. 2013; Capozzi et al. 2019) which opened the doors to the practice of simultaneous inoculum in grape must of these two microbial populations. However, it is hypothisable, observing the result of experiments performed at T3, that the co-presence of yeast and LAB in grape must at the beginning of AF makes microorganisms more sensitive to environmental stress factors, and in particular at the high temperature of fermentation. In G1 experiments, an incomplete AF was observed in T3 experiment, residing in wine with $3 \mathrm{~g} / \mathrm{L}$ of sugars. This result is quite singular considering the low selective pressure that G1 exerts over microorganisms (Alcohol content around $11 \%$, Table 3) and that the maximum temperature reached $\left(32{ }^{\circ} \mathrm{C}\right)$, although unusual for the strain Lalvin ICVD47, within the survival range of the $S$. cerevisiae, and commonly employed in the reactivation of ADY (Rodríguez-Porrata et al. 2008).

In our opinion, the increase in yeast sensitivity to wine limiting factors due to the simultaneous presence of LAB becomes more evident in the experiments carried out in G2. In these conditions, S. cerevisiae was unable to conclude AF at the $\mathrm{T} 3$ temperature profile, leaving more than $30 \mathrm{~g} / \mathrm{L}$ of sugar in the wine (Table 3). The ethanol potential of G2, around 13.5\% (Table 3), should not represent a limit for selected yeast strains (Carrasco et al. 2001). Therefore, the causes of incomplete AF could be researched in the yeast sensitivity to high temperature of fermentation that, in our hypothesis, could be due to the interaction between yeast and LAB. Flow cytometric analysis would seem to confirm this hypothesis (Fig. 3). Under the T3 conditions, the yeast population suffered a rapid decline. This should not be surprising since the interaction, negative for cells, between ethanol and high temperatures in determining alterations of the cellular membrane is known (Woo et al. 2014). However, attention must be given to the fact that the two stress factors are detrimental for yeast even at such low values. The hypothesis suggested by the authors regarding the increase in the sensitivity of yeasts to stress factors in the presence of LAB could have relevant oenological implications and, therefore, must be confirmed with further tests.

The experimental plan envisaged the use of two strains of LAB with different characteristics. L. plantarum $\mathrm{K} 45 \mathrm{H}$ is a homofermentative bacteria with poor tolerance to acidity. It is suitable for use in wine in the presence of sugar residues because an eventual glucose/fructose intake cannot cause the accumulation of acetic acid in wine (Guerzoni et al. 1995). O. oeni A4 is a heterofermentative microorganism with a proven resistance to difficult MLF conditions due to 
the presence of limiting environmental factors (Lonvaud-Funel 1999; Guzzon et al. 2009). In experiments performed in G1, L. plantarum $\mathrm{K} 45 \mathrm{H}$ resulted more efficient in the consumption of malic acid independently of $\mathrm{pH}$ and temperature. O. oeni A4 sustained reliable behavior at the first two temperature profiles (T1 and T2) although the conclusion of the MLFs was generally delayed with respect to the $\mathrm{K} 45 \mathrm{H}$ strain, probably because the strain of $O$. oeni accumulated a lower amount of cells (Table 1). Tests carried out with the A4 strain at $\mathrm{T} 3$ did not register cell growth below $6 \log$ units (Table 1) and consequently, the degradation of malic acid did not occur (Table 2). In the test performed in G2, both bacteria showed an increased sensitivity to fermentation temperature, resulting in the inability to conclude MLF in the tests carried out at T3. As for the yeasts, these results are unexpected because the characteristics of the grape must were not so selective as to inhibit LAB activity (Liu 2002; Guzzon et al. 2009). Again, it can be assumed that the coexistence of two microbial populations reduces their resistance to sub-optimal environmental conditions and, among these, to high fermentation temperature. Between the two species of lactic bacteria, $O$. oeni appeared the least suitable for simultaneous fermentation at high temperature. In G2T3 tests, the stopping of AF in the presence of an $O$. oeni population led to an increase in volatile acidity (Table 3 ) that is probably caused by the heterofermentation of sugars by bacteria. It is interesting to note that in the same conditions the activity of $L$. plantarum, a homofermentative bacteria, induces a slight increase in the concentration of lactic acid, without the accumulation of acetic acid (Table 2).

The GC-MS analysis of wine volatile profiles underlined differences referable both to the features of the grape musts and the technological variables adopted in experimental winemaking. An extensive discussion about the changes in the profile of volatile compounds of wines linkable to the ripeness of grapes is outside the topic of this work. However, it is plausible that the high number of volatile compounds found in G2 samples, which explains their positioning in the quadrant designed by the negative values of the 1 st and 2 nd factors of PCA (Fig. 4 a and b), was correlated at the accumulation kinetics of volatiles during grape ripening. The different technological variables tested (temperature and LAB strains) do not seem to have minimized these differences, since the wine samples obtained from G1 and G2 are clearly differentiated in the PCA analysis. This result could respond to doubts, frequently advanced by winemakers, regarding the use of selected cultures of yeasts and bacteria and the risks that these may standardize the features of wines, reducing their typicality. Just a delay of about 10 days in the harvest time of grapes, coming from the same vineyard, was able to segregate the obtained wines in a more significant way than some technological variables, such as the yeast or bacteria strain and the fermentation temperature. However, in both grape musts, the strain of bacteria and the fermentation temperature caused differences in the volatile profile of wines, evident in the PCA analysis. The fermentation temperature was the most significant factor in the determining the features of wines. This observation is confirmed by the statistical treatment of data of Table 2 and 3 (two-way ANOVA test) and by the positioning of cases (wine samples) in the plane described from the first two variables of the PCA (Fig. 4). Considering that, for a large part of the compounds, the concentration in wine is inversely correlated to the 1 st variable, it is evident that the increase in fermentation temperature causes a loss of volatile molecules, both for G1 and for G2 samples. This effect is maximized in the G2T3 sample, but shows a similar trend in G1 samples. Among the two strains of LABs, wines made by A4 had a lower content of volatile molecules, especially at the extreme T1 and T3 temperature profiles, while at T2, the profile of wines made by the different LAB strains almost overlap. These results fit well with the microbiological observation that underlined the stress exerted by high temperatures on LAB activity. The sensitivity of $S$. cerevisiae to high-fermentation temperature was recently confirmed by Pattanakittivorakul et al. (2019) who characterized some species of yeast in order to improve bioethanol production. Schwinn et al. (2019) observed differences in volatile accumulation by $S$. cerevisiae when increasing the temperature from 14 to $19{ }^{\circ} \mathrm{C}$. Similarly, experiments performed in cider by Herero et al. (Herrero et al. 1999a, 1999b, Herrero et al. 2006) indicated that the LAB metabolism's optimum activity is round $22-25{ }^{\circ} \mathrm{C}$, with a reduction in acetic acid accumulation and the best efficiency in malic acid consumption. Temperatures above $30{ }^{\circ} \mathrm{C}$ affect the performances of bacteria, and in particular of $O$. oeni, with a reduction in malic acid degradation and an increase in fructose assimilation, potentially dangerous due to the accumulation of acetic acid (Pimentel et al. 1994; Woo et al. 2014). Regarding the comparison between Lactobacillus sp. and Oenococcus sp., back in 1994, Guerzoni et al. had already observed that the first genera showed the best resistance at the simultaneous action of different limiting factors at sub-lethal level, the same situation that is observable in G2.

In conclusion, this work enhances knowledge on the simultaneous fermentation of yeast and bacteria in wine confirming the potential interest of this practice in winemaking. However, the results obtained suggest that the behavior of microorganisms, both in terms of resistance 
to limiting factors and in the production of valuable metabolites, is affected by the interaction of different and highly concentrated microbial populations that coexist in the same environment. Therefore, a careful choice of the yeast and bacteria strain and the control of fermentation temperature are mandatory to prevent wine deterioration due to the loss of valuable volatile fractions and the accumulation of unpleasant compounds, such as acetic acid.

\section{Acknowledgements}

We thank Sergio Moser, Mario Malacarne, and Giovanna Facchinelli (Edmund Mach Foundation) and Paola Vagnoli, Sibylle Krieger-Weber (Lallemand Inc.) who provided ideas, insight, and expertise that greatly assisted the research.

\section{Authors' contributions}

Guzzon Raffaele and Larcher Roberto have made substantial contributions to conception and design, or acquisition of data, or analysis and interpretation of data. Tomas Roman has been involved in drafting the manuscript or revising it critically for important intellectual content. The authors read and approved the final manuscript.

\section{Funding}

The products used in the experiments (Yeast and bacteria) were provided free of charge from Lallemand Inc. The costs due to this work were borne by the ordinary funds of the Edmund Mach Foundation and by Lallemand inc. contribution.

\section{Ethics approval and consent to participate}

N/A

\section{Competing interests}

The authors declare that they have no conflict of interest. All experiments were performed in total autonomy and without any pressure or interference from external companies or financiers

Received: 5 August 2019 Accepted: 23 April 2020

Published online: 29 June 2020

\section{References}

Alexandre H, Costello PJ, Remize F, Guzzo J, Guilloux-Benatier M (2004) Saccharomyces cerevisiae-Oenococcus oeni interactions in wine: current knowledge and perspectives. Int J Food Microbiol 93(2):141-154

Azzolini M, Tosi E, Veneri G, Zapparoli G (2010) Evaluating the efficacy of lysozyme against lactic acid bacteria under different winemaking scenarios. $S$ Afr J Enol Vitic 31(2):99-105

Barata A, Malfeito-Ferreira M, Loureiro V (2012) The microbial ecology of wine grape berries. Int J Food Microbiol 153(3):243-259

Bartowsky J (2009) Bacterial spoilage of wine and approaches to minimize it. Lett Appl Microbiol 48(2):149-156

Battermann G, Radler F (1991) A comparative study of malolactic enzyme and malic enzyme of different lactic acid bacteria. Can J Microbiol 37(3):211-217

Betteridge A, Grbin P, Jiranek V (2015) Improving Oenocccus oeni to overcome challenges of wine malolactic fermentation. Trends Biotechnol 33(9):547-553

Boido E, Lloret A, Medina K, Farina L, Carrau F, Versini G, Dellacassa E (2003) Aroma composition of Vitis vinifera cv. Tannat: the typical red wine from Uruguay. J Ag Food Chem 51:5408-5413

Bordiga M, Lorenzo C, Pardo F, Salinas MR, Travaglia F, Arlorio M, Coïsson JD, Garde-Cerdán T (2016) Factors influencing the formation of histaminol, hydroxytyrosol, tyrosol, and tryptophol in wine: temperature, alcoholic degree, and amino acids concentration. Food Chem 197:1038-1045

Capozzi V, Berbegal C, Tufariello M, Grieco F, Spano G, Grieco F (2019) Impact of co-inoculation of Saccharomyces cerevisiae, Hanseniaspora uvarum and Oenococcus oeni autochthonous strains in controlled multi starter grape must fermentations. LWT Food Sci Technol 109:241-249

Carrasco P. Querol A del Olmo M (2001) Analysis of the stress resistance of commercial wine yeast strains. Arch Microbiol 175(6):450-457
Costello PJ, Henschke PA, Markides AJ (2003) Standardized methodology for testing malolactic bacteria and wine yeast compatibility. Au J Grape Wine Res 9(2):127-137

Costello PJ, Henschke PA, Markides AJ (2008) Standardised methodology for testing malolactic bacteria and wine yeast compatibility. Au J Grape Wine Res 9:127-137

Elmac SB, Gülgör G, Tokatl M, Erten H, Işci A, Özçelik F (2014) Effectiveness of chitosan against wine-related microorganisms. Antonie Van Leeuwenhoek 107:675-686

Gambetta JM, Cozzolino D, Bastian SEP, Jeffery DW (2016) Towards the creation of a wine quality prediction index: correlation of chardonnay juice and wine compositions from different regions and quality levels. Food Anal Methods 9(10):2842-2855

Garbay S, Rozes N, Lonvaud-Funel A (1995) Fatty-acid composition of Leuconostoc oenos, incidence of growth-conditions and relationship with malolactic efficiency. Food Microbiol 12(5):387-395

Guerzoni ME, Sinigaglia M, Gardini F, Ferruzzi M, Torriani S (1995) Effects of pH, temperature, ethanol, and malate concentration on Lactobacillus plantarum and Leuconostoc oenos. Modeling of the malolactic activity. Am J Enol Vitic 46(3):368-374

Guzzon R, Larcher R (2015) The application of flow cytometry in microbiological monitoring during winemaking: two case studies. Ann Microbiol 65(4):1865-1878

Guzzon R, Poznanski E, Conterno L, P. Vagnoli P, Krieger-Weber S (2009) Selection of a new highly resistant strain for malolactic fermentation under difficult conditions. S Afr J Enol Vitic 30(2):133

Guzzon R, Roman Villega T, Pedron M, Malacarne M, Nicolini G, Larcher R (2013) Simultaneous yeast-bacteria inoculum. A feasible solution for the management of oenological fermentation in red must with low nitrogen content. Ann Microbiol 63(2):805-808

Herrero M, Cuesta I, Garcia LA, Díaz M (1999a) Changes in organic acids during malolactic fermentation at different temperatures in yeast-fermented apple juice. J I Brew 105(3):191-195

Herrero M, Garcia LA, Diaz M (1999b) Organic acids in cider with simultaneous inoculation of yeast and malolactic bacteria: effect of fermentation temperature. J I Brew 105(4):229-232

Herrero M, Garcia LA, Diaz M (2006) Volatile compounds in cider: inoculation time and fermentation temperature effects. J I Brew 112(3):210-214

ISO/IEC 17011 (2017) Conformity assessment — requirements for accreditation bodies accrediting conformity assessment bodies. ISO, Geneve

Jussier D, Dubé Morneau A, Mira de Orduña R (2006) Effect of simultaneous inoculation with yeast and bacteria on fermentation kinetics and key wine parameters of cool-climate chardonnay. Appl Environ Microbiol 72(1):221-227. https://doi.org/10.1128/AEM.72.1.221-227.2006

Lasik-Kurdyś M, Majcher M, Nowak J (2018) Effects of different techniques of malolactic fermentation induction on diacetyl metabolism and biosynthesis of selected aromatic esters in cool-climate grape wines. Molecules 23(10):2549

Liu SQ (2002) A review: malolactic fermentation in wine - beyond deacidification. J Appl Microbiol 92(4):589-601. https://doi.org/10.1046/j.1365-2672.2002.01589x

Lonvaud-Funel A (1999) Lactic acid bacteria in the quality improvement and depreciation of wine. Antonie Van Leeuwenhoek 76(1-4):317-331

Matthews A, Grimaldi A, Walker M, Bartowsky E, Grbin P, Jiranek V (2004) Lactic acid bacteria as a potential source of Smit G, Smit BA, Engels WJM (2005) Flavor formation by lactic acid bacteria and biochemical flavor profiling of cheese products. FEMS Microbial Rev 29(3):591-610

Michlmayr H, Kneifel W (2014) ß-glucosidase activities of lactic acid bacteria: mechanisms, impact on fermented food and human health. FEMS Microbiol Lett 352(1):1-10

Nielsen JC, Richelieu M (1999) Control of flavor development in wine during and after malolactic fermentation by Oenococcus oeni. Appl Environ Microbiol 65(2):740-745

OIV (2019) Microbiological analysis of wines and musts. Paris (F).

Pattanakittivorakul S, Lertwattanasakul N, Yamada M, Limtong S (2019) Selection of thermotolerant Saccharomyces cerevisiae for high temperature ethanol production from molasses and increasing ethanol production by strain improvement. Antonie Van Leeuwenhoek 112:975-990

Pimentel MS, Silva MH, Cortes I, Mendes Faia A (1994) Growth and metabolism of sugar and acids of Leuconostoc oenos under different conditions of temperature and $\mathrm{pH}$. J Appl Microbiol 76(1):42-48

Rodríguez-Porrata B, Novo M, Guillamón RN, Mas A, Cordero Otero R (2008) Vitality enhancement of the rehydrated active dry wine yeast. Int J Food Microbiol 126:116-122 
Schwinn M, Durner D, Wacker M, Delgado A, Fischer U (2019) Impact of fermentation temperature on required heat dissipation, growth and viability of yeast, on sensory characteristics and on the formation of volatiles in Riesling. Au J Grape Wine Res 25(2):173-184

Setford PC, Jeffery DW, Grbin PR (2018) Mathematical modelling of anthocyanin mass transfer to predict extraction in simulated red wine fermentation scenarios. Food Res Int 121:705-713

Smit GDS, Smit BA, Engels WJM (2005) Flavour formation by lactic acid bacteria and biochemical flavour profiling of cheese products. FEMS Microbiol Rev 29: $591-610$

Su J, Wang T, Wang Y, Li YY, Li H (2014) The use of lactic acid-producing, malic acid-producing, or malic acid-degrading yeast strains for acidity adjustment in the wine industry. Appl Microbiol Biotechnol 98:2395-2413

Sumby KM, Bartle L, Grbin PR, Jiranek V (2019) Measures to improve wine malolactic fermentation. Appl Microbiol Biotechnol 103(5):2033-2051

Sumby KM, Grbin PR, Jiranek V (2014) Implications of new research and technologies for malolactic fermentation in wine view web of science applied microbiology and biotechnology. Appl Microbiol Biotechnol 98(19): $8111-8132$

Taniasuri F, Lee PR, Liu SQ (2016) Induction of simultaneous and sequential malolactic fermentation in durian wine. Int J Food Microbiol 230(2):1-9

Vrhovsek U, Rigo A, Tonon D, Mattivi F (2004) Quantitation of polyphenols in different apple varieties. J Ag Food Chem 52:6532-6538

Wang PX, Li AX, Sun HY, Dong M, Wei XY, Fan MT (2016) Selection and characterization of Oenococcus oeni strains for use as new malolactic fermentation starter cultures. Ann Microbiol 66:1285-1292

Woo JM, Yang KM, Kim SU, Blank LM, Park JB (2014) High temperature stimulates acetic acid accumulation and enhances the growth inhibition and ethanol production by Saccharomyces cerevisiae under fermenting conditions. App Micrbiol Biotechnol 98(13):6085-6094

\section{Publisher's Note}

Springer Nature remains neutral with regard to jurisdictional claims in published maps and institutional affiliations.

Ready to submit your research? Choose BMC and benefit from:

- fast, convenient online submission

- thorough peer review by experienced researchers in your field

- rapid publication on acceptance

- support for research data, including large and complex data types

- gold Open Access which fosters wider collaboration and increased citations

- maximum visibility for your research: over $100 \mathrm{M}$ website views per year

At $\mathrm{BMC}$, research is always in progress.

Learn more biomedcentral.com/submissions 